\title{
Sulphate retention: a simplified method for categorizing soils into allophanic and non-allophanic Andosols
}

\author{
Junko TAKAHASHI \& Teruo HIGASHI \\ Faculty of Life and Environmental Sciences, University of Tsukuba ${ }^{1}$
}

\begin{abstract}
Summary
Unlike phosphate, an index of sulphate retention of soils has not commonly been defined. However, sulphate sorption by soils is more sensitive than phosphate sorption to the amount of their colloidal components. Sulphate has less sorption affinity than some organic acids or phosphate, and is sorbed by hydrous $\mathrm{Al} / \mathrm{Fe}$ such as allophane but not by $\mathrm{Al}$-humus complexes. Therefore, we attempted to categorize soils as allophanic or non-allophanic Andosols by sorption experiments of sulphate. The method employed for sulphate retention (S-retention) was based on the common method for P-retention, using potassium sulphate solution (3.12 $\mathrm{mmol} \mathrm{SO}_{4}{ }^{2-} \mathrm{1}^{-1}$, equivalent to $100 \mathrm{mgS} \mathrm{l}^{-1}$ ) buffered by potassium acetate ( $\mathrm{pH} \mathrm{4.0)}$ and shaking for one hour with a soil:solution ratio of 1:5. In the results from 172 soil samples of 30 forest soils in eastern Japan, a linear regression was obtained between S-retention and $\mathrm{Al}_{\mathrm{o}}+1 / 2 \mathrm{Fe}_{\mathrm{o}}(r=0.780, P<0.001)$. All aluandic (non-allophanic) soil samples $\left(\mathrm{Si}_{\mathrm{o}}\right.$ $<0.6 \%$ and $\mathrm{Al}_{\mathrm{p}}: \mathrm{Al}_{\mathrm{o}}>0.5$, in accordance with the WRB classification system) had poor S-retention $(<60 \%)$ and were clearly divided from silandic (allophanic) soil samples. Highly weathered Cambisols with small activity ratios of free iron oxides $\left(\mathrm{Fe}_{\mathrm{o}}: \mathrm{Fe}_{\mathrm{d}}<0.4\right)$ tended to have greater S-retention $(>30 \%)$ than less weathered Umbrisols and Cambisols with $\mathrm{Fe}_{\mathrm{o}}: \mathrm{Fe}_{\mathrm{d}}>0.4$. In addition, these four soil types were separated as distinct domains on a scatter diagram of P-retention plotted against S-retention.
\end{abstract}

\section{Introduction}

Non-allophanic Andosols were first found in Japan (Shoji \& Ono, 1978). Before this discovery, it was considered that the unique properties of Andosols such as large organic matter content, much phosphate fixation, good water retention and small bulk density were due to the presence of short-rangeordered allophone minerals. Although non-allophanic Andosols also have these properties, they are dominated by 2:1 layer silicates and aluminium/iron ( $\mathrm{Al} / \mathrm{Fe})$-humus complexes. Shoji (1985) subsequently showed that the genesis of nonallophanic Andosols can be attributed mainly to the leaching of silica and the formation of Al-Fe humus complexes caused by supply of a large amount of organic matter under acid conditions $(\mathrm{pH}<5)$ with large rainfalls. Therefore, nonallophanic Andosols in Japan are distributed in high rainfall regions such as the area adjacent to the Sea of Japan, and the Chubu district, and account for about $30 \%$ of the total (Saigusa $\&$ Matsuyama, 1998). However, there are many reports about soil profiles which have non-allophanic properties in the upper A horizon and allophanic properties in the lower part of the A horizon (Kubotera et al., 2009; Van Ranst et al., 2008). Vacca et al. (2003) showed that allophanic and non-allophanic soils in the Roccamonfina volcano, Italy, co-existed in similar landscapes under similar climatic conditions, and concluded that allophanic soils developed in younger tephra than nonallophanic soils. It is presumed that the distribution of these two types of Andosols forms a mosaic in volcanic areas. The occurrence of non-allophanic Andosols in non-volcanic areas has also been recently found in many regions. According to Delvaux et al. (2004), non-allophanic Andosols in Europe are linked with Hercynian rocks in highlands with a cool and humid climate and often co-exist with Cambisols and Podzols, suggesting that non-allophanic Andosols can be regarded as further developed Cambisols with increasing Al-Fe humus complexes, and as poorly developed Podzols after carbon stabilization. The non-allophanic Andosols had a larger percentage of water-stable aggregates and a smaller carbon mineralization rate compared than Podzols, and the Al-Fe humus complexes was immobile in the non-allophanic Andosols (Aran et al., 2001). In addition, Caner et al. (2000; 2011) found several non-allophanic Andosols derived from highly weathered soils and showed that the accumulation of organic matter in the top-soil resulted in dissolution of their secondary minerals such as gibbsite and crystalline iron oxides, and gradually replaced these with sufficient organo-metallic complexes to produce andic properties. Vacca et al. (2009) pointed out that andic soil properties should not just be defined according to the parent material, and the distribution of soil with andic properties might be more widespread than assumed.

\footnotetext{
${ }^{1}$ 1-1-1 Ten-nou-dai, Tsukuba, Ibaraki 305-8572, Japan

Correspondence: J. Takahashi. E-mail: takahashi.junko.ka@u.tsukuba.ac.jp

Received 18 July 2013; revised version accepted 13 August 2014
} 
The world distribution and total area of non-allophanic Andosols have yet to be clarified fully, including in Japan.

On the other hand, it is well known that non-allophanic Andosols have lower soil $\mathrm{pH}$ and more extractable $\mathrm{Al}$ and organic carbon than allophanic Andosols (Shoji et al., 1993). Therefore, it is important for not only fertilizer management but also for understanding of carbon storage to identify both types of Andosol accurately. However, it is impossible to distinguish them by morphological characteristics in the field, and so it is necessary to do this from chemical and mineralogical properties.

According to the latest Japanese soil classification system (Obara et al., 2011), the phosphate absorption coefficient or phosphate retention provide diagnostic criteria for Andosols and their andic properties. However, in order to classify Andosols into allophanic or non-allophanic Andosols it is necessary to determine the acid-oxalate extractable $\mathrm{Al}, \mathrm{Fe}$ and Silicon ( $\mathrm{Al}_{0}, \mathrm{Fe}_{\mathrm{o}}$ and $\mathrm{Si}_{\mathrm{o}}$, respectively) and the pyrophosphate extractable $\mathrm{Al}\left(\mathrm{Al} \mathrm{p}_{\mathrm{p}}\right.$ ) or exchangeable acidity $(\mathrm{y} 1)$. In the WRB system (IUSS Working Group WRB, 2006), the values of $\mathrm{Al}_{0}$ and $\mathrm{Fe}_{\mathrm{o}}$ are essential criteria of andic properties. In other words, the phosphate absorption coefficient or phosphate retention are not included as important components of second-level units of Andosols because the phosphate ion is sorbed not only by allophane but also by Al-humus complexes.

Sulphate ions are specifically adsorbed on the surface of hydrated Al minerals through ligand exchange reactions as well as phosphate ions (Rajan, 1978). However, the amounts of adsorbed sulphate are decreased by the presence of organic acids (Martinez et al., 1998) or phosphate (Kamprath et al., 1956), suggesting that these anions compete for the adsorption sites with sulphate ions and displace them. Moreover, it was found that allophanic Andosols in Japan retain significantly larger amounts of sorbed sulphate (phosphate-extractable sulphate) than brown forest soils (with no andic properties) or other soils reported in North America and Europe (Tanikawa et al., 2003). However, Takahashi \& Higashi (2013) reported that the amounts of sorbed sulphate in non-allophanic Andosols were similar to those in brown forest soils. These results suggest that sulphate ions have less sorption affinity than some organic acids or phosphate, and are sorbed by hydrated Al materials such as allophane but not by Al-humus complexes.

In the present study, in order to separate allophanic Andosols from non-allophanic Andosols we conducted sulphate sorption experiments using the normal method for phosphate retention (Blakemore et al., 1987) using samples of various soil types under forest vegetation. We also propose a simplified method for categorizing soils on the criteria of extractable $\mathrm{Al}$ and $\mathrm{Fe}$ in combination with sorption of sulphate (S-retention) and phosphate (P-retention).

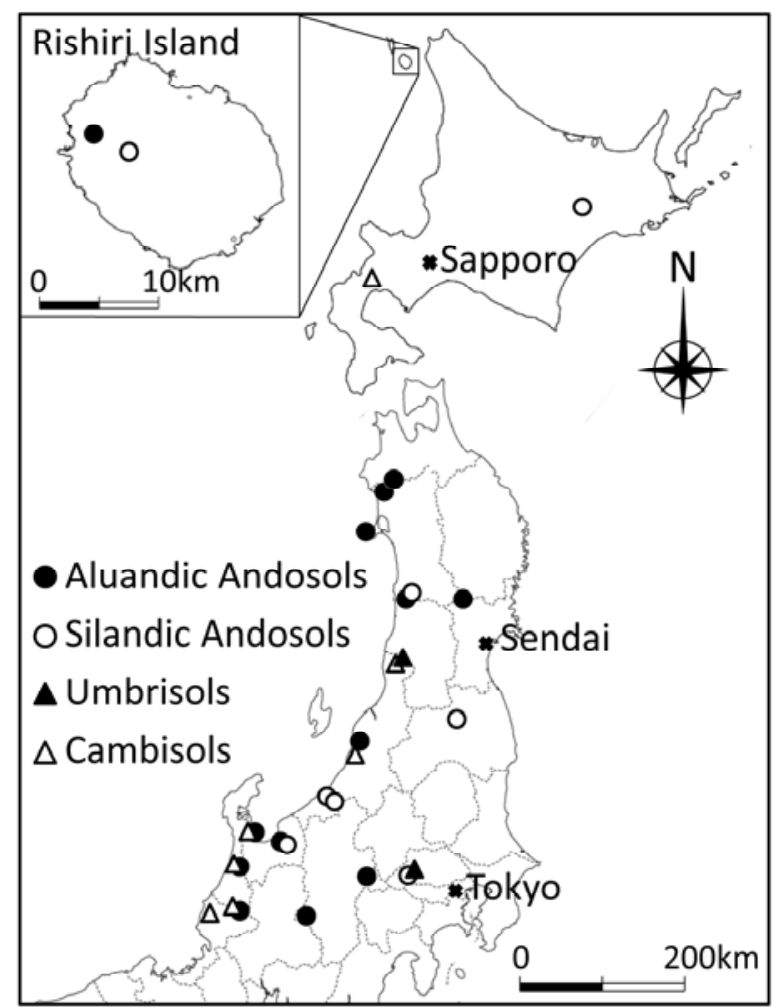

Figure 1 Locations of the study sites.

\section{Materials and methods}

\section{Soil samples}

Soil samples (a total of 172) were taken from each horizon of 30 soil profiles under forest vegetation in eastern Japan (Figure 1). The soil profiles were classified as 13 aluandic Andosols, eight silandic Andosols, two Umbrisols and seven Cambisols as classified by the WRB system. These samples came from areas with mean annual temperatures of $6.3-15.2^{\circ}$ C, annual precipitation of $895-2640 \mathrm{~mm}$ and altitudes of 44 $1350 \mathrm{~m}$ above sea level. The parent materials of Andosols are mainly cumulative volcanic ashes and those of Umbrisols and Cambisols are igneous and sedimentary rocks. Vegetation is broad-leaved deciduous forest dominated by Fagus crenata Blume or Quercus crispula Blume and evergreen needle-leaf forest dominated by Pinus densiflora Siebold \& Zucc. Only natural or secondary forests were included. The details including the chemical properties of some of these soil profiles were previously described by Takahashi \& Higashi (2013).

\section{Analytical methods}

All soil samples were air-dried and passed through a $2 \mathrm{~mm}$ or $0.5 \mathrm{~mm}$ sieve prior to chemical analyses. Acid oxalateextractable $\mathrm{Al}, \mathrm{Fe}$ and $\mathrm{Si}\left(\mathrm{Al}_{\mathrm{o}}, \mathrm{Fe}_{\mathrm{o}}\right.$ and $\mathrm{Si}_{\mathrm{o}}$ ), pyrophosphateextractable $\mathrm{Al}$ and $\mathrm{Fe}\left(\mathrm{Al}_{\mathrm{p}}\right.$ and $\left.\mathrm{Fe}_{\mathrm{p}}\right)$ and dithionite-citrateextractable $\mathrm{Al}$ and $\mathrm{Fe}\left(\mathrm{Al}_{\mathrm{d}}\right.$ and $\left.\mathrm{Fe}_{\mathrm{d}}\right)$ were extracted according 
to Blakemore et al. (1987). The pyrophosphate extracts were centrifuged with Accofloc and then passed through a $0.025-\mu \mathrm{m}$ membrane filter to remove colloidal iron compounds. The Al, $\mathrm{Fe}$, and $\mathrm{Si}$ concentrations were determined by inductively coupled plasma atomic emission spectrophotometry (ICPAES) using ICPS-8100 (Shimadzu, Tokyo, Japan). Soil pH was measured in $\mathrm{H}_{2} \mathrm{O}$ and $1 \mathrm{M} \mathrm{KCl}$ (soil:solution 1:2.5). Exchangeable $\mathrm{Al}$ in the $1 \mathrm{M} \mathrm{KCl}$ extracts was determined by ICP-AES. Total carbon (TC) and total nitrogen (TN) were determined by dry combustion using an $\mathrm{NC}$ analyser (Sumigraph NC-900, Sumika Chemical Analysis Service, Tokyo, Japan). Phosphate retention (P-retention) was measured according to Blakemore et al. (1987) by shaking samples for 16 hours with potassium dihydrogen phosphate solution (1000 $\mathrm{mgP}^{-1}, \mathrm{pH} \mathrm{4.6)}$ at a soil:solution ratio of 1:5. Phosphate concentrations were determined by the vanadomolybdate spectrophotometric method with a V-660 instrument (JASCO Corporation, Tokyo, Japan).

\section{Sorption of sulphate (S-retention)}

Unlike phosphate, the index of sulphate retention or sorption capability of soils has not been commonly defined although numerous sulphate-sorption experiments have been conducted under various conditions. On the other hand, many characteristics related to sulphate sorption, especially sulphate concentration and solution $\mathrm{pH}$, have been investigated. Thus apparent sulphate sorption increases exponentially at equilibrium concentrations $>100 \mathrm{mmol} \mathrm{SO}_{4}{ }^{2-} 1^{-1}$ because of precipitation (Ishiguro et al., 2004). Delfosse et al. (2006) reported that $\mathrm{Al}_{\mathrm{x}}(\mathrm{OH})_{\mathrm{y}}\left(\mathrm{SO}_{4}\right)_{\mathrm{z}}$ minerals might be formed under large sulphate concentrations ( $>6 \mathrm{mmol} \mathrm{SO}_{4}{ }^{2-} \mathrm{l}^{-1}$ ). In addition, Barreal et al. (2001) showed that sorption of sulphate tended to be about one tenth of that of phosphate sorption. On the basis of these results and the standard experiment conditions for phosphate retention (Blakemore et al., 1987), in the present study we adopted $100 \mathrm{mgS} \mathrm{l}^{-1}\left(3.12 \mathrm{mmol} \mathrm{SO}_{4}{ }^{2-} \mathrm{l}^{-1}\right)$ potassium sulphate as our standard condition.

Pigna \& Violante (2003) reported that the sorption of sulphate by Andosols was almost absent at $\mathrm{pH}>5.5$ and increased with soil acidification. However, Nodvin et al. (1986) showed that samples from spodic horizons sorb maximum amounts of sulphate at $\mathrm{pH} 4$ because the dissolution of the solid phase of sorbent begins at $\mathrm{pH}<3.5$. Therefore, a preliminary assessment of sulphate sorption by one allophanic Andosol sample was conducted at $\mathrm{pH} 3.0$ to 6.0 in potassium acetate buffer. In addition, the effect of shaking time (ranging from one minute to 16 hours) on sulphate sorption was tested using the same sample. The results, discussed later, showed that $\mathrm{pH} 4.0$ and one hour were optimal for measurement of Sretention.
Sulphate-retention solution was prepared according to the following procedure. Anhydrous potassium sulphate (1.089 g) and anhydrous potassium acetate $(3.926 \mathrm{~g})$ were dissolved in $1.8 \mathrm{~L}$ water, and glacial acetic acid (about $9 \mathrm{ml}$ ) added to bring the mixture to $\mathrm{pH} 4.0$. This was made up to volume with water in a 2-L volumetric flask. A sorption experiment was conducted by shaking this solution for one hour at $25^{\circ} \mathrm{C}$ with soil sample at a soil:solution ratio of 1:5. After centrifugation, the liquid phase was filtered through a $0.45-\mu \mathrm{m}$ membrane filter and sulphate concentration determined by ion chromatography (HIC-SP; Shimadzu, Tokyo, Japan).

\section{Results and discussion}

\section{Effects of pH and shaking time on sulphate sorption}

Two preliminary experiments were conducted to determine suitable $\mathrm{pH}$ and shaking time for sulphate sorption. The soil sample studied was from a Bw horizon with allophanic soil properties. The values of $\left(\mathrm{Al}_{\mathrm{o}}+1 / 2 \mathrm{Fe}_{\mathrm{o}}\right), \mathrm{Si}_{\mathrm{o}}$, exchangeable $\mathrm{Al}$ and native sorbed sulphate (phosphate-extractable sulphate) were $53.1 \mathrm{~g} \mathrm{~kg}^{-1}, 27.3 \mathrm{~g} \mathrm{~kg}^{-1}, 51.8 \mathrm{mg} \mathrm{kg}^{-1}$ and $17.3 \mathrm{mmol} \mathrm{kg}$ ${ }^{1}$, respectively. The equilibrium $\mathrm{pH}$ values of the supernatant after shaking were within the $\mathrm{pH}$ of the original added solutions \pm 0.2 in all cases. As shown in Figure 2, the amount of sulphate sorbed from the added solution was greatest at $\mathrm{pH}$ 3.5-4.0 and decreased with both increasing and decreasing $\mathrm{pH}$. On the other hand, the amount of Al dissolved from soil drastically increased at $\mathrm{pH}<3.5$, as reported by Nodvin et al. (1986). The amount of sulphate sorption slightly increased with shaking time (Figure 3). However, the difference between one hour and 16 hours was less than $2 \%$, indicating that the equilibrium was approximately reached within one hour. Therefore, $\mathrm{pH} 4.0$ and one hour were employed throughout in this study.

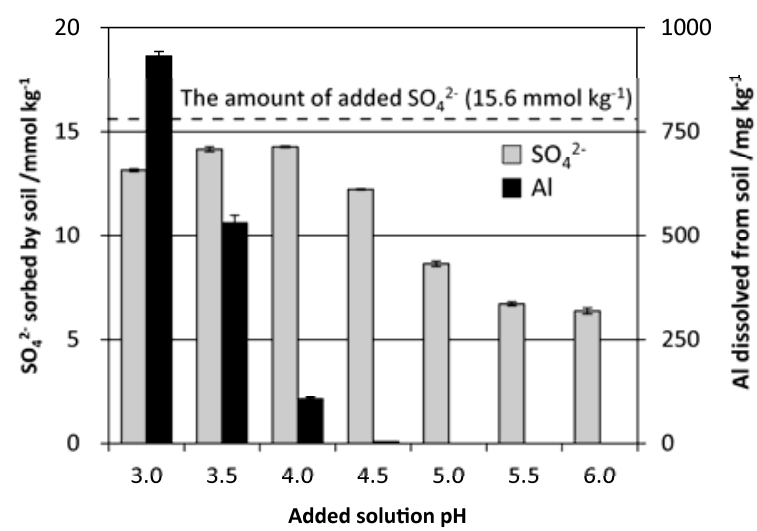

Figure 2 Amounts of sulphate sorbed by, and $\mathrm{Al}$ dissolved from one silandic soil sample at $\mathrm{pH} 3.0$ to 6.0 using potassium sulphate solution $\left(100 \mathrm{mgS} \mathrm{l}^{-1}\right)$ buffered by potassium acetate. Error bars $=$ standard deviation. 


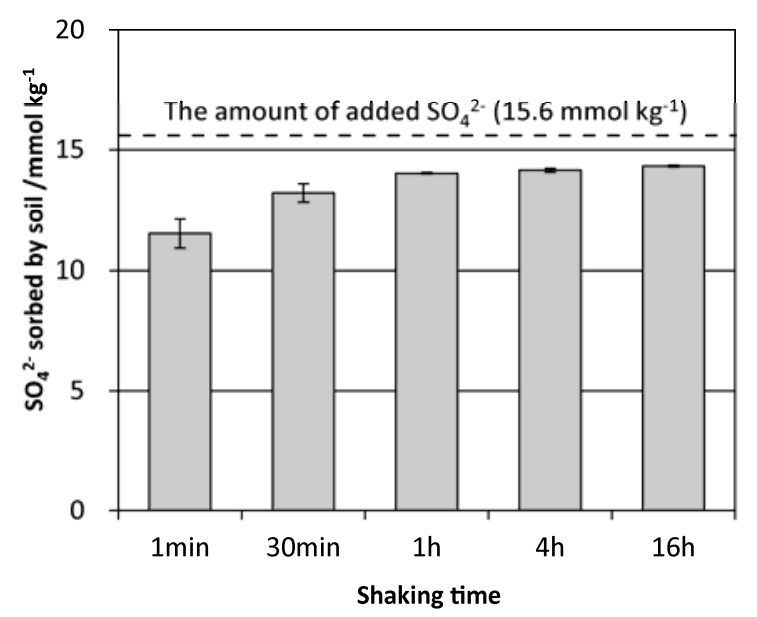

Figure 3 Amounts of sulphate sorbed by one silandic soil sample at different shaking time (ranged from one minute to 16 hours). Error bars $=$ standard deviation.

It is to be noted that the amount of added sulphate (15.6 mmol $\left.\mathrm{kg}^{-1}\right)$ was less than the native sorbed sulphate $(17.3$ mmol $\mathrm{kg}^{-1}$ ) of this sample in our experiment conditions. According to previous research, the amounts of native sorbed sulphate in most non-volcanic soils (not Andosols) are $<2$ mmol kg-1 (e.g. Singh, 1980; Johnson \& Todd, 1983), while those in some volcanic Andosols are $>20 \mathrm{mmol} \mathrm{kg}^{-1}$ ( Hasan et al., 1970; Tanikawa et al., 2003). Therefore, the S-retention values under our experiment conditions should not be regarded as total sorption capacity.

\section{Comparison of the chemical properties of soil samples by soil type}

Table 1 summarises the means and ranges of some chemical properties of soil samples for A and B horizons from each soil type. Although there was no a great difference in the $\mathrm{pH}_{\mathrm{H} 2 \mathrm{O}}$ between A horizons of either type of Andosol, the mean value of $\mathrm{pH}_{\mathrm{H} 2 \mathrm{O}}$ of B horizons in aluandic Andosols was 4.92, lower than for silandic Andosols (5.21). In agreement with Shoji (1985), the formation of allophane has been inhibited under acid conditions $(<\mathrm{pH} 5)$. The $\mathrm{pH}$ values in $\mathrm{KCl}(\mathrm{pHKCl})$ of silandic Andosols were higher than those of aluandic Andosols for both A and B horizons. In accordance with this result, the amounts of exchangeable $\mathrm{Al}$ of silandic Andosols were less than those of aluandic Andosols. Umbrisols and Cambisols had low $\mathrm{pH}_{\mathrm{KCl}}$ values and large amounts of exchangeable $\mathrm{Al}$ similar to aluandic Andosols. Total carbon values in Cambisols were clearly smaller, but there was little difference among other three soil types, unlike Shoji et al. (1993)'s study who reported that aluandic Andosols can accumulate more organic carbon than silandic Andosols. Only the $\mathrm{Al}_{o}$ and $\mathrm{Si}_{\mathrm{o}}$ contents of silandic Andosols were greater than those of aluandic Andosols. On the other hand, extractable Al, $\mathrm{Fe}$ (except $\mathrm{Fe}_{\mathrm{d}}$ ) and $\mathrm{Si}$ of Umbrisols and Cambisols were smaller than those of Andosols, indicating that $\mathrm{Fe}$ oxides predominate in Umbrisols and Cambisols unlike Andosols which are dominated by short-range-ordered iron oxyhydroxides. According to the US Soil Survey Staff (2004), Al $\mathrm{d}_{\mathrm{d}}$ represents the Al-humus complexes plus the $\mathrm{Al}$ substituted in Fe oxides $\left(\mathrm{Al}_{\text {sub }}\right)$. In our study, good correlation between $\left(\mathrm{Al}_{\mathrm{d}}-\mathrm{Al}_{\mathrm{p}}\right)$ and $\left(\mathrm{Fe}_{\mathrm{d}}-\mathrm{Fe}_{\mathrm{p}}\right)$ was obtained in Umbrisols and Cambisols $(r=0.832$, $P<0.001)$, suggesting that $\left(\mathrm{Al}_{d}-\mathrm{Al}_{\mathrm{p}}\right)$ represents $\mathrm{Al}_{\text {sub. However, }}$. in Andosols $\left(\mathrm{Al}_{\mathrm{d}}-\mathrm{Al}_{\mathrm{p}}\right)$ correlated well with $\mathrm{Al}_{\mathrm{o}}(r=0.736, P$ $<0.001)$ rather than with $\left(\mathrm{Fe}_{\mathrm{d}}-\mathrm{Fe}_{\mathrm{p}}\right)(r=0.310, P<0.05)$. Therefore, we consider that $\mathrm{Al}_{\mathrm{d}}$ of Andosols represents the $\mathrm{Al}$ partly dissolved from allophane or Al-humus complexes (Parfitt \& Childs, 1988).

\section{Characteristics of phosphate and sulphate retention}

The amount of sulphate sorbed from $100 \mathrm{mgS} \mathrm{l}^{-1}$ solution (S-retention) was calculated as percent $\mathrm{S}$ retained, as with $\mathrm{P}$ retention (Blakemore et al., 1987). The results of analyses of 172 soil samples indicated that the distribution of S-retention was even and symmetrical around a central score (40-50\%). However, the values of P-retention were more than $70 \%$ in 144 samples, and less than $50 \%$ in only eight samples.

With the relationships between P-retention or S-retention and $\mathrm{Al}_{\mathrm{o}}+1 / 2 \mathrm{Fe}_{\mathrm{o}}$ (Figures 4 and 5), a logarithmic regression was obtained for P-retention ( $r=0.863, P<0.001)$, agreeing with the relationships reported by Shoji et al. (1993). However, a linear regression was obtained for S-retention $(r=0.780, P$ $<0.001)$. According to the WRB system, an $\mathrm{Al}_{o}+1 / 2 \mathrm{Fe}_{\mathrm{o}}$ value of $20 \mathrm{~g} \mathrm{~kg}^{-1}$ or more and a P-retention of $85 \%$ or more are required for andic properties. The approximate curve obtained from P-retention passed close to the intersection of these criteria lines (Figure 4), confirming that P-retention is useful for identifying andic properties. In fact, the latest Japanese soil classification system (Obara et al., 2011) requires only the Pretention or phosphate absorption coefficient as the diagnostic criteria of andic properties. On the other hand, the values of Sretention even in Andosols varied from 0\% to 99\%, although the sulphate concentration of the S-retention standard solution was only one tenth of the phosphate concentration of $\mathrm{P}$ retention solution (Figure 5). The Cambisols and Umbrisols samples tended to deviate upward from this regression line, indicating these soils have greater sulphate retention in relation to $\mathrm{Al}_{\mathrm{o}}$ and $\mathrm{Fe}_{\mathrm{o}}$ contents. Therefore, it is assumed that sorbents other than $\mathrm{Al}_{o}$ and $\mathrm{Fe}_{\mathrm{o}}$ are important for S-retention of these soils. The correlation coefficients between extractable $\mathrm{Al} / \mathrm{Fe}$ and S- or P-retention are shown in Table 2 in order to help to identify the dominant sorbent by soil type. Results from Cambisols and Umbrisols were combined for statistical analysis because the number of Umbrisol samples was small. 
Table 1 Chemical properties of soil samples by soil type.

\begin{tabular}{|c|c|c|c|c|c|c|c|c|}
\hline & \multicolumn{4}{|l|}{ A horizons } & \multicolumn{4}{|l|}{ B horizons } \\
\hline & $\begin{array}{l}\text { Aluandic } \\
\text { Andosols } \\
(\mathrm{n}=37)\end{array}$ & $\begin{array}{l}\text { Silandic } \\
\text { Andosols } \\
(\mathrm{n}=24)\end{array}$ & $\begin{array}{l}\text { Umbrisols } \\
(\mathrm{n}=4)\end{array}$ & $\begin{array}{l}\text { Cambisols } \\
(\mathrm{n}=12)\end{array}$ & $\begin{array}{l}\text { Aluandic } \\
\text { Andosols } \\
(\mathrm{n}=34)\end{array}$ & $\begin{array}{l}\text { Silandic } \\
\text { Andosols } \\
\text { (n-28) }\end{array}$ & $\begin{array}{l}\text { Umbrisols } \\
(\mathrm{n}=5)\end{array}$ & $\begin{array}{l}\text { Cambisols } \\
(\mathrm{n}=28)\end{array}$ \\
\hline $\mathrm{pH}_{\mathrm{H} 2 \mathrm{O}}$ & $\begin{array}{l}4.70 \\
(3.47-5.51)\end{array}$ & $\begin{array}{l}4.77 \\
(3.8-5.58)\end{array}$ & $\begin{array}{l}5.21 \\
(4.30-5.55)\end{array}$ & $\begin{array}{l}4.61 \\
(4.02-4.92)\end{array}$ & $\begin{array}{l}4.92 \\
(4.02-5.63)\end{array}$ & $\begin{array}{l}5.21 \\
(4.68-5.98)\end{array}$ & $\begin{array}{l}5.19 \\
(4.78-5.61)\end{array}$ & $\begin{array}{l}4.95 \\
(4.68-5.26)\end{array}$ \\
\hline $\mathrm{pH}_{\mathrm{KCl}}$ & $\begin{array}{l}3.88 \\
(2.85-4.63)\end{array}$ & $\begin{array}{l}4.07 \\
(3.26-4.69)\end{array}$ & $\begin{array}{l}3.60 \\
(3.30-3.96)\end{array}$ & $\begin{array}{l}3.68 \\
(2.94-4.12)\end{array}$ & $\begin{array}{l}4.23 \\
(3.36-4.84)\end{array}$ & $\begin{array}{l}4.73 \\
(4.07-5.28)\end{array}$ & $\begin{array}{l}4.06 \\
(3.95-4.18)\end{array}$ & $\begin{array}{l}3.90 \\
(3.68-4.25)\end{array}$ \\
\hline $\begin{array}{l}\text { Total Carbon } \\
\qquad / \mathrm{g} \mathrm{kg}^{-1}\end{array}$ & $\begin{array}{l}108.5 \\
(33.1-222.8)\end{array}$ & $\begin{array}{l}145.0 \\
(64.1-295.6)\end{array}$ & $\begin{array}{l}124.7 \\
(54.3-218.9)\end{array}$ & $\begin{array}{l}63.0 \\
(19.8-201.3)\end{array}$ & $\begin{array}{l}37.8 \\
(4.4-125.2)\end{array}$ & $\begin{array}{l}48.7 \\
(15.9-115.0)\end{array}$ & $\begin{array}{l}25.7 \\
(2.4-83.3)\end{array}$ & $\begin{array}{l}8.8 \\
(0.2-22.0)\end{array}$ \\
\hline $\mathrm{Al}_{\mathrm{o}} / \mathrm{g} \mathrm{kg}^{-1}$ & $\begin{array}{l}16.0 \\
(3.6-33.5)\end{array}$ & $\begin{array}{l}26.5 \\
(2.4-74.8)\end{array}$ & $\begin{array}{l}9.0 \\
(7.2-10.2)\end{array}$ & $\begin{array}{l}7.1 \\
(3.0-11.9)\end{array}$ & $\begin{array}{l}22.5 \\
(6.4-47.6)\end{array}$ & $\begin{array}{l}43.6 \\
(12.2-86.1)\end{array}$ & $\begin{array}{l}7.4 \\
(2.5-13.8)\end{array}$ & $\begin{array}{l}6.8 \\
(2.7-13.5)\end{array}$ \\
\hline $\mathrm{Fe}_{o} / \mathrm{g} \mathrm{kg}^{-1}$ & $\begin{array}{l}15.0 \\
(6.8-24.6)\end{array}$ & $\begin{array}{l}13.4 \\
(2.4-25.3)\end{array}$ & $\begin{array}{l}11.3 \\
(10.1-12.3)\end{array}$ & $\begin{array}{l}6.5 \\
(3.3-9.8)\end{array}$ & $\begin{array}{l}18.1 \\
(4.4-33.9)\end{array}$ & $\begin{array}{l}19.4 \\
(7.5-36.2)\end{array}$ & $\begin{array}{l}7.0 \\
(2.2-11.7)\end{array}$ & $\begin{array}{l}5.9 \\
(1.7-13.0)\end{array}$ \\
\hline $\mathrm{Si}_{0} / \mathrm{g} \mathrm{kg}^{-1}$ & $\begin{array}{l}1.14 \\
(0-7.4)\end{array}$ & $\begin{array}{l}6.5 \\
(0-23.7)\end{array}$ & $\begin{array}{l}0.2 \\
(0-0.3)\end{array}$ & $\begin{array}{l}0.4 \\
(0-1.4)\end{array}$ & $\begin{array}{l}4.6 \\
(0.2-20.7)\end{array}$ & $\begin{array}{l}15.8 \\
(0.9-33.1)\end{array}$ & $\begin{array}{l}0.5 \\
(0-1.0)\end{array}$ & $\begin{array}{l}0.7 \\
(0.2-3.0)\end{array}$ \\
\hline $\mathrm{Al}_{\mathrm{p}} / \mathrm{g} \mathrm{kg}^{-1}$ & $\begin{array}{l}11.1 \\
(2.7-20.3)\end{array}$ & $\begin{array}{l}13.7 \\
(2.2-33.6)\end{array}$ & $\begin{array}{l}7.2 \\
(6.2-7.9)\end{array}$ & $\begin{array}{l}4.5 \\
(2.3-6.4)\end{array}$ & $\begin{array}{l}10.3 \\
(1.9-20.1)\end{array}$ & $\begin{array}{l}9.7 \\
(4.7-27.3)\end{array}$ & $\begin{array}{l}5.0 \\
(0.8-10.2)\end{array}$ & $\begin{array}{l}3.3 \\
(1.2-6.3)\end{array}$ \\
\hline $\begin{array}{l}\mathrm{Fe}_{\mathrm{p}} \\
\quad / \mathrm{g} \mathrm{kg}^{-1}\end{array}$ & $\begin{array}{l}8.1 \\
(4.1-13.8)\end{array}$ & $\begin{array}{l}7.7 \\
(1.6-13.6)\end{array}$ & $\begin{array}{l}8.0 \\
(7.3-8.7)\end{array}$ & $\begin{array}{l}3.8 \\
(2.0-6.0)\end{array}$ & $\begin{array}{l}7.4 \\
(1.0-18.9)\end{array}$ & $\begin{array}{l}4.1 \\
(0.4-12.2)\end{array}$ & $\begin{array}{l}4.0 \\
(0.2-7.4)\end{array}$ & $\begin{array}{l}2.4 \\
(0.2-5.2)\end{array}$ \\
\hline $\mathrm{Al}_{\mathrm{d}} / \mathrm{g} \mathrm{kg}^{-1}$ & $\begin{array}{l}12.7 \\
(3.3-21.2)\end{array}$ & $\begin{array}{l}18.3 \\
(3.9-28.5)\end{array}$ & $\begin{array}{l}8.9 \\
(6.9-10.7)\end{array}$ & $\begin{array}{l}6.1 \\
(2.8-9.5)\end{array}$ & $\begin{array}{l}14.6 \\
(3.9-28.5)\end{array}$ & $\begin{array}{l}17.6 \\
(4.1-32.0)\end{array}$ & $\begin{array}{l}6.0 \\
(1.4-11.1)\end{array}$ & $\begin{array}{l}6.0 \\
(1.6-9.2)\end{array}$ \\
\hline $\mathrm{Fe}_{\mathrm{d}} / \mathrm{g} \mathrm{kg}^{-1}$ & $\begin{array}{l}17.1 \\
(9.1-28.0)\end{array}$ & $\begin{array}{l}13.0 \\
(2.0-21.3)\end{array}$ & $\begin{array}{l}16.9 \\
(12.7-19.7)\end{array}$ & $\begin{array}{l}12.6 \\
(5.9-17.3)\end{array}$ & $\begin{array}{l}19.5 \\
(5.6-33.8)\end{array}$ & $\begin{array}{l}15.6 \\
(5.2-28.3)\end{array}$ & $\begin{array}{l}10.8 \\
(2.9-14.6)\end{array}$ & $\begin{array}{l}15.2 \\
(3.7-35.0)\end{array}$ \\
\hline $\begin{array}{l}\text { Exchangeable } \\
\mathrm{Al} / \mathrm{mg} \mathrm{kg}^{-1}\end{array}$ & $\begin{array}{l}459.6 \\
(15.1-1421.8)\end{array}$ & $\begin{array}{l}269.2 \\
(7.1-790.5)\end{array}$ & $\begin{array}{l}682.8 \\
(560.5-854.7)\end{array}$ & $\begin{array}{l}625.5 \\
(293.6-1357.5)\end{array}$ & $\begin{array}{l}441.9 \\
(25.6-1892.7)\end{array}$ & $\begin{array}{l}108.7 \\
(10.9-410.4)\end{array}$ & $\begin{array}{l}371.9 \\
(255.8-455.4)\end{array}$ & $\begin{array}{l}617.0 \\
(158.2-2131.9)\end{array}$ \\
\hline
\end{tabular}

For each parameter, the upper line shows the mean value and the lower line shows the range (minimum - maximum) values.

Table 2 Correlation coefficients $(r)$ between extractable $\mathrm{Al} / \mathrm{Fe}$ and phosphate or sulphate retention.

\begin{tabular}{|c|c|c|c|c|c|c|c|c|c|c|c|}
\hline & & \multicolumn{5}{|l|}{$\mathrm{Al}$} & \multicolumn{5}{|l|}{$\mathrm{Fe}$} \\
\hline & & $\mathrm{Al}_{\mathrm{d}}$ & $\mathrm{Al}_{\circ}$ & $\mathrm{Al}_{\mathrm{p}}$ & $\mathrm{Al}_{\mathrm{d}}-\mathrm{Al}_{\mathrm{p}}$ & $\mathrm{Al}_{\mathrm{o}}-\mathrm{Al}_{\mathrm{p}}$ & $\mathrm{Fe}_{\mathrm{d}}$ & $\mathrm{Fe}_{\mathrm{o}}$ & $\mathrm{Fe}_{\mathrm{p}}$ & $\mathrm{Fe}_{\mathrm{d}}-\mathrm{Fe}_{\mathrm{p}}$ & $\mathrm{Fe}_{\mathrm{o}}-\mathrm{Fe}_{\mathrm{p}}$ \\
\hline \multicolumn{12}{|l|}{ S-retention } \\
\hline Aluandic Andosols & $(\mathrm{n}=71)$ & 0.677 & 0.827 & $\underline{0.369}$ & 0.526 & 0.776 & 0.392 & 0.546 & -0.062 & 0.499 & 0.668 \\
\hline Silandic Andosols & $(\mathrm{n}=52)$ & 0.485 & 0.848 & 0.018 & 0.566 & 0.880 & $\underline{0.308}$ & 0.453 & -0.549 & 0.695 & 0.689 \\
\hline Other soil types & $(\mathrm{n}=49)$ & 0.478 & 0.392 & -0.026 & 0.799 & 0.663 & 0.677 & 0.170 & -0.214 & 0.753 & 0.466 \\
\hline \multicolumn{12}{|l|}{ P-retention } \\
\hline Aluandic Andosols & $(\mathrm{n}=71)$ & 0.714 & 0.647 & 0.650 & 0.284 & 0.421 & 0.368 & 0.480 & 0.129 & 0.344 & 0.464 \\
\hline Silandic Andosols & $(\mathrm{n}=52)$ & 0.565 & 0.623 & 0.381 & 0.472 & 0.565 & 0.426 & 0.438 & -0.064 & 0.513 & 0.462 \\
\hline Other soil types & $(\mathrm{n}=49)$ & 0.880 & 0.879 & 0.711 & 0.416 & 0.613 & 0.463 & 0.622 & 0.440 & $\underline{0.300}$ & 0.487 \\
\hline
\end{tabular}

Values in underline, italic and bold type are significant at the $0.05,0.01$, and 0.001 probability levels, respectively.

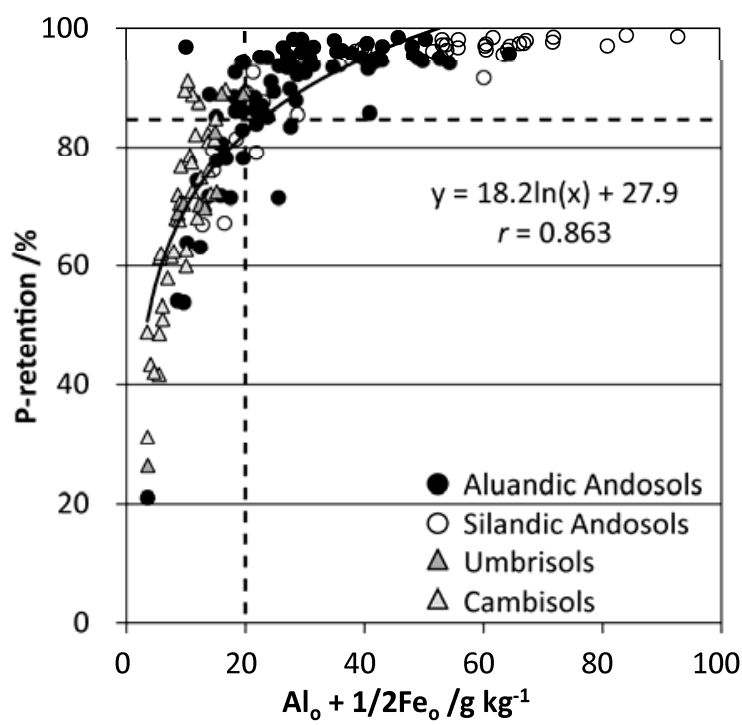

Figure 4 Relationship between $\mathrm{Al}_{\mathrm{o}}+1 / 2 \mathrm{Fe}_{\mathrm{o}}$ and P-retention of 172 soil samples. The two broken lines shows the diagnostic criteria of andic properties according to the WRB system.

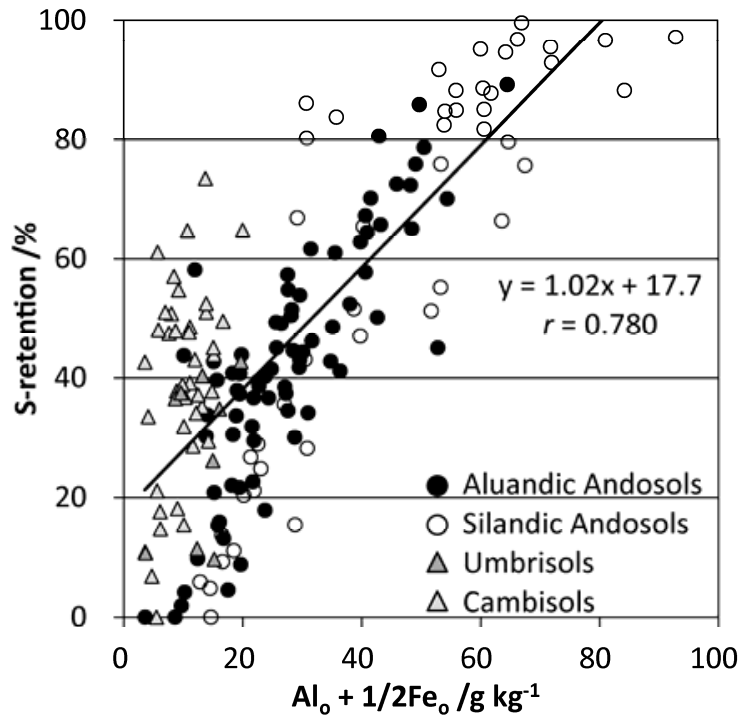

Figure 5 Relationship between $\mathrm{Al}_{\mathrm{o}}+1 / 2 \mathrm{Fe}_{\mathrm{o}}$ and S-retention of 172 soil samples. 


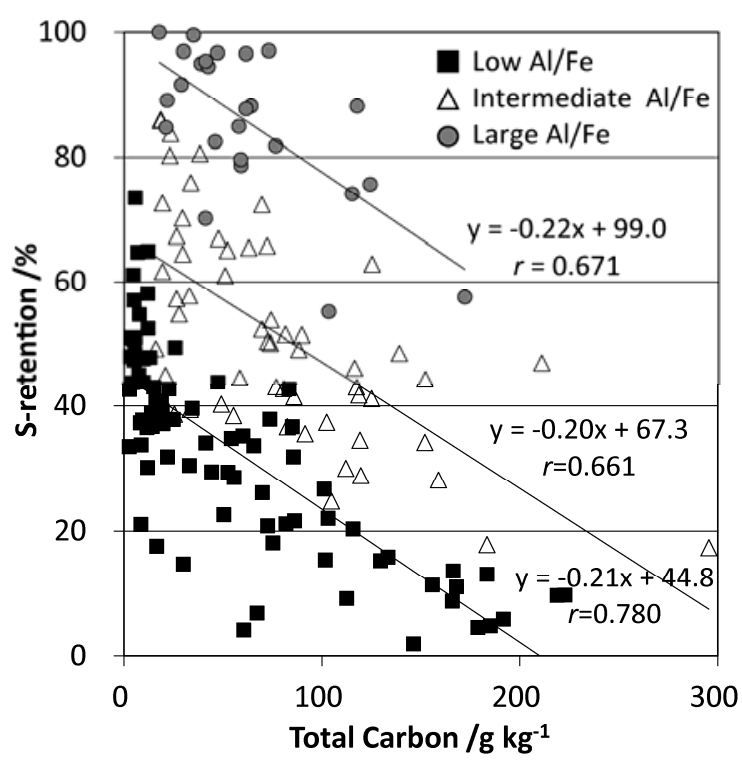

Figure 6 Relationship between Total carbon and S-retention. Low $\mathrm{Al} / \mathrm{Fe}$ samples are $\left(\mathrm{Al}_{0}+1 / 2 \mathrm{Fe}_{\mathrm{o}}\right)<20 \mathrm{~g} \mathrm{~kg}^{-1}$, intermediate $\mathrm{Al} / \mathrm{Fe}$ samples are $20 \mathrm{~g} \mathrm{~kg}^{-1}<\left(\mathrm{Al}_{0}+1 / 2 \mathrm{Fe}_{\mathrm{o}}\right)<50 \mathrm{~g} \mathrm{~kg}^{-1}$, and large $\mathrm{Al} / \mathrm{Fe}$ samples are $\left(\mathrm{Al}_{0}+1 / 2 \mathrm{Fe}_{\mathrm{o}}\right)>50 \mathrm{~g} \mathrm{~kg}^{-1}$.

For S-retention, both Andosols had similar trends of correlation coefficients, but Cambisols and Umbrisols had poorer correlation with $\mathrm{Al}_{\mathrm{o}}$ and $\mathrm{Fe}_{\mathrm{o}}$ and better correlation with $\left(\mathrm{Al}_{d}-\mathrm{Al}_{\mathrm{p}}\right)$ and $\mathrm{Fe}_{\mathrm{d}}$ than for Andosols. As discussed previously, $\left(A l_{d}-A l_{p}\right)$ in Cambisols and Umbrisols represents the $\mathrm{Al}_{\text {sub }}$ in Fe oxides. Barreal et al. (2003) reported that goethite with more $\mathrm{Al}_{\text {sub }}$ had greater sulphate sorption capacity because specific surface area increased by substitution of Al. Therefore, it is considered that not only $\mathrm{Fe}_{\mathrm{d}}$ but also $\left(\mathrm{Al}_{\mathrm{d}}-\mathrm{Al}_{\mathrm{p}}\right)$ contribute to increase S-retention in these soil types. Whereas in Pretention, all soil types had similar trends and positive correlations were found between every extractable $\mathrm{Al} / \mathrm{Fe}$ category except $\mathrm{Fe}_{\mathrm{p}}$. Unlike P-retention, there was no correlation between $\mathrm{Al}_{\mathrm{p}}$ and S-retention, suggesting that sulphate was not sorbed by Al-humus complexes. Moreover, for soil samples with similar $\mathrm{Al}_{\mathrm{o}}+1 / 2 \mathrm{Fe}_{\mathrm{o}}$ contents, S-retention tended to decrease with increasing soil organic carbon (Figure $6)$.

\section{Categorizing method using S-retention and P-retention}

Since it is clear that the dominant sorbents of sulphate were different between Andosols and Umbrisols/Cambisols, further correlation analysis was performed for each soil type. Figure 7 shows the relationship between S-retention and the dominant sorbents $\left[\left(\mathrm{Al}_{\mathrm{o}}-\mathrm{Al} \mathrm{l}_{\mathrm{p}}\right)+\left(\mathrm{Fe}_{\mathrm{o}}-\mathrm{Fe}_{\mathrm{p}}\right)\right]$ for Andosols: closed circles are soil samples with the criteria for aluandic Andosols $\left(\mathrm{Si}_{\mathrm{o}}\right.$ $<0.6 \%$ and $\mathrm{Al}_{\mathrm{p}}: \mathrm{Al}_{\mathrm{o}}>0.5$ ) based on the WRB system. The values of S-retention in all aluandic samples were less than

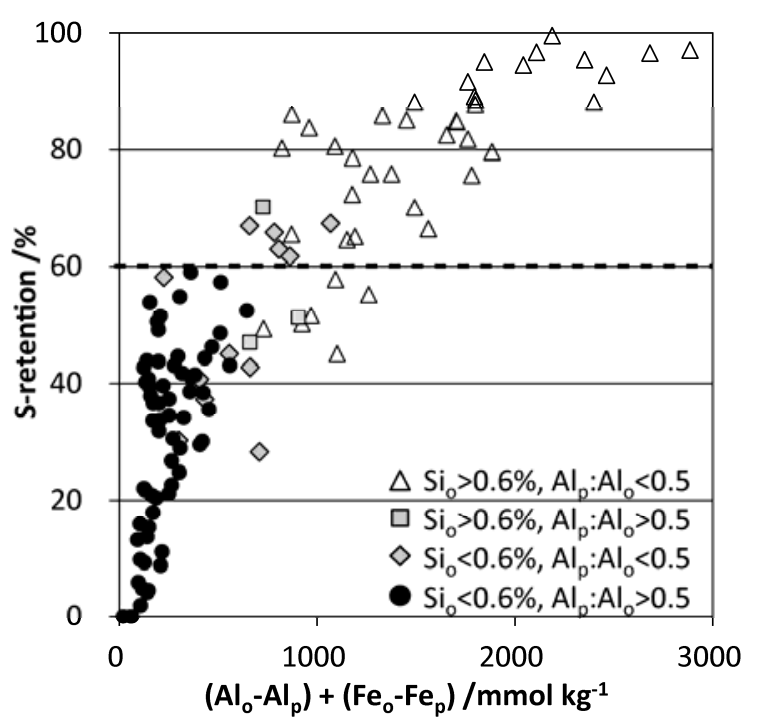

Figure 7 Relationship between $\left[\left(\mathrm{Al}_{\mathrm{o}}-\mathrm{Al}_{\mathrm{p}}\right)+\left(\mathrm{Fe}_{\mathrm{o}}-\mathrm{Fe}_{\mathrm{p}}\right)\right]$ and S-retention of Andosols. All aluandic samples (O) have S-retention $<60 \%$ as indicated by the broken line.

$60 \%$ and were clearly separated from silandic samples $\left(\mathrm{Si}_{\circ}\right.$ $>0.6 \%$ or $\mathrm{Al}_{\mathrm{p}}: \mathrm{Al}_{\mathrm{o}}<0.5$ ). Unlike the WRB system, the criteria for aluandic Andosols in the Japanese soil classification system (Obara et al., 2011) is $\mathrm{Si}_{o}<0.6 \%$ or $\mathrm{Al}_{\mathrm{p}}: \mathrm{Al}_{\mathrm{o}}>0.5$. In this case, aluandic soil samples were separated from silandic samples by the criterion of S-retention $<70 \%$. In Soil Taxonomy (Soil Survey Staff, 2010), there is no criteria to categorize either allophanic or non-allophanic Andosols although the classification scheme for the new soil order of Andisols was first published by Soil Survey Staff (1990).

Some silandic soil samples with S-retention of $<60 \%$ contained large amounts of total carbon $\left(>100 \mathrm{~g} \mathrm{~kg}^{-1}\right)$ or Sirich allophane (molar ratio of $\left.\left(\mathrm{Al}_{\mathrm{o}}-\mathrm{Al}_{\mathrm{p}}\right): \mathrm{Si}_{\mathrm{o}}<1.6\right)$. Delmelle et al. (2003) reported that Al-rich allophane might permit more sulphate sorption at the mineral surface because allophane with a $\left(\mathrm{Al}_{\mathrm{o}}-\mathrm{Al} \mathrm{l}_{\mathrm{p}}\right)$ : $\mathrm{Si}$ o ratio close to 2 develops variable negative and positive charges than does Si-rich allophane. This explains why our samples had less S-retention than typical silandic samples.

With Umbrisols and Cambisols, a stronger correlation was obtained between S-retention and $\left[\left(\mathrm{Al}_{\mathrm{d}}-\mathrm{Al}_{\mathrm{p}}\right)+\left(\mathrm{Fe}_{\mathrm{d}}-\mathrm{Fe}_{\mathrm{p}}\right)\right]$ rather than $\left[\left(\mathrm{Al}_{\mathrm{o}}-\mathrm{Al}_{\mathrm{p}}\right)+\left(\mathrm{Fe}_{\mathrm{o}}-\mathrm{Fe}_{\mathrm{p}}\right)\right]$ (Figure 8$)$. Soil samples with a small activity ratio of free iron oxides $\left(\mathrm{Fe}_{\mathrm{o}}: \mathrm{Fe}_{\mathrm{d}}<0.4\right)$ tended to have greater S-retention ( $>30 \%)$ : this ratio is used as a relative measure of the degree of aging or crystallinity of free iron oxides (Blume \& Schwertmann, 1969). According to Nagatsuka (1972), the criterion of $\mathrm{Fe}_{\mathrm{o}}: \mathrm{Fe}_{\mathrm{d}}<0.4$ is useful to differentiate 'yellow-brown forest soil' which develops in the warm-temperate region of Japan. This soil type usually does 


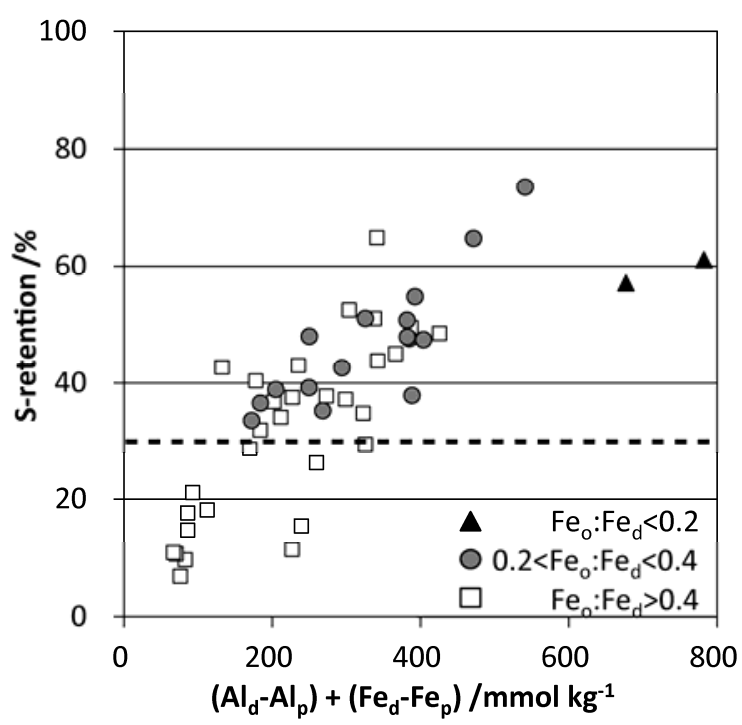

Figure 8 Relationship between $\left[\left(\mathrm{Al}_{\mathrm{d}}-\mathrm{Al}_{\mathrm{p}}\right)+\left(\mathrm{Fe}_{\mathrm{d}}-\mathrm{Fe}_{\mathrm{p}}\right)\right]$ and S-retention of Umbrisols and Cambisols. Highly weathered Cambisols with a small activity ratio of free iron oxides $\left(\mathrm{Fe}_{0}: \mathrm{Fe}_{\mathrm{d}}<0.4\right)$ tend to have a relatively large S-retention (>30\%) as indicated by the broken line.

not have a definite Argic horizon, however it is more highly weathered than 'brown forest soil' in the cold-temperate region but less weathered than 'red-yellow soils' in the humid subtropical climate region of Japan. In regions such as Japan, which are covered by relatively young soils, it is important in the management of agriculture and forestry to divide Cambisols into brown forest soil and yellow-brown forest soil. The trend of soils with a small activity ratio having a large Sretention was not found for P-retention, for which the values were little different regardless of the amount of extractable $\mathrm{Al} / \mathrm{Fe}$ or ratio of $\mathrm{Fe}_{\mathrm{o}}: \mathrm{Fe}_{\mathrm{d}}$.

The trends of P-retention and S-retention are different for each soil type as the scatter diagram of P-retention and Sretention in Figure 9 shows. Using the criteria of extractable $\mathrm{Al}$ and $\mathrm{Fe}$ from the WRB system and the activity ratio, each soil sample was easily categorized as follows: (i) P-retention $>85 \%$ and S-retention $>60 \%$ are silandic soils; (ii) P-retention $>85 \%$ and S-retention $<60 \%$ are aluandic soils; (iii) $\mathrm{P}$ retention $<85 \%$ and S-retention $>30 \%$ are samples of highly weathered Cambisols with $\mathrm{Fe}_{\mathrm{o}}: \mathrm{Fe}_{\mathrm{d}}<0.4$ (yellow-brown forest soils); and (iv) P-retention $<85 \%$ and S-retention $<30 \%$ are samples of Umbrisols or Cambisols with $\mathrm{Fe}_{\mathrm{o}}: \mathrm{Fe}_{\mathrm{d}}>0.4$ (brown forest soil).

The amounts of native sorbed sulphate of the forest soil samples used in this study ranged from 0.15 to $47.7 \mathrm{mmol} \mathrm{kg}$ ${ }^{1}$, so we considered this method to be useful regardless of the content of native sulphate in the case of forest soils. However, it is necessary to assess its applicability to agricultural soil samples heavily fertilized with phosphate. In addition, only the amounts of extractable $\mathrm{Al}$ and $\mathrm{Fe}$ were discussed as the sorbent

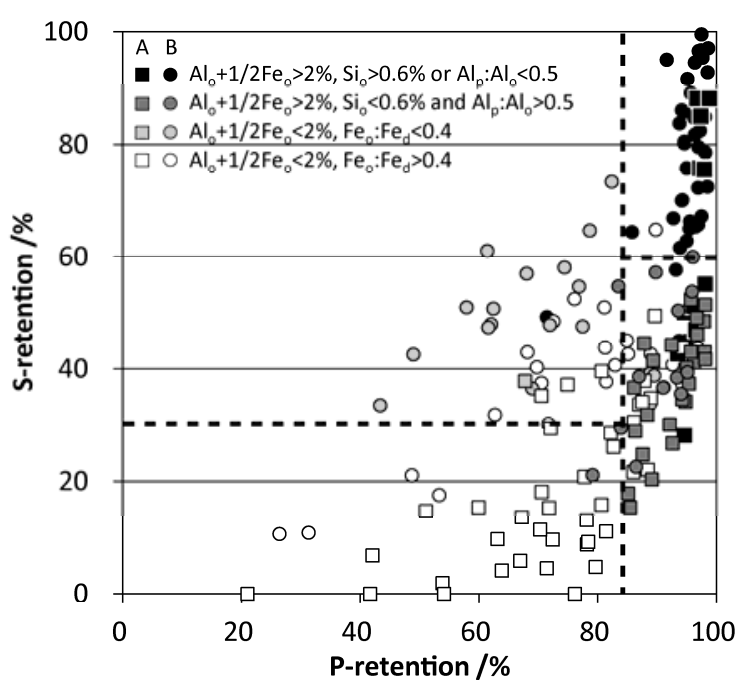

Figure 9 Scatter diagram of P-retention and S-retention. A vertical broken line marks P-retention of $85 \%$; the two horizontal broken lines are at S-retention of $60 \%$ and $30 \%$.

of sulphate in the present study. However, the amount of sulphate sorption cannot be necessarily predicted on the dominant type of the minerals or their contents (Barreal et al., 2003), and depends more on the degree of crystallinity and the specific surface than on the total content (Borggaard, 1983). Further mineralogical study is required to understand the characteristics of sulphate sorption by soils with more complicated colloidal components such as aluandic Andosols derived from highly weathered soils reported by Caner et al. (2000).

\section{Conclusions}

The sulphate-sorption experiment (sulphate retention) was conducted by modifying the common method for phosphate retention. The results from correlation analyses with extractable $\mathrm{Al}$ and $\mathrm{Fe}$ showed that the characteristics of sulphate retention are different from phosphate retention. Namely, little sulphate is sorbed by $\mathrm{Al}$-humus complexes $\left(\mathrm{Al}_{\mathrm{p}}\right)$, and the values of sulphate retention even in Andosols varied from $0 \%$ to $99 \%$ and closely reflect the amount of extractable $\mathrm{Al}$ and $\mathrm{Fe}$. Therefore, sulphate retention in the present study can be proposed as a simplified method for categorizing Andosols into silandic and aluandic Andosols. Moreover, Fe oxides $\left(\mathrm{Fe}_{\mathrm{d}}\right.$ and $\left.\mathrm{Al}_{\mathrm{sub}}\right)$ largely contribute to sulphate retention in non-Andosols with small amounts of $\mathrm{Al}_{\mathrm{o}}$ and $\mathrm{Fe}_{\mathrm{o}}$, indicating that highly weathered Cambisols has relatively large sulphate retention despite of low phosphate retention. Since the amounts of these anion sorption might be determined by the quantity and quality of the colloids in soils, it would be possible to develop a more effective method for categorizing 
soils using the combination of different characteristics of anion sorption. Further study is required to obtain the chemical and mineralogical information on the sorption of sulphate.

\section{Acknowledgements}

We would like to thank the OPEN FACILITY, Research Facility Center for Science and Technology, University of Tsukuba, for allowing us to carry out ICPS- 8100 measurements of $\mathrm{Al}, \mathrm{Fe}$ and $\mathrm{Si}$. This work was supported by a Grant-in-Aid for JSPS Fellows Number 10J00388.

\section{References}

Aran, D., Gury, M. \& Jeanroy, E. 2001. Organo-metallic complexes in an Andosol: a comparative study with a Cambisol and Podzol. Geoderma, 99, 65-79.

Barreal, M.E., Arbestain, M.C., Macías, F. \& Fertitta, A.E. 2001. Phosphate and sulfate retention by nonvolcanic soils with andic properties. Soil Science, 166, 691-707.

Barreal, M.E., Arbestain, M.C. \& Macías, F. 2003. Chemical properties and soil color of some Oxisols from Brazil and Spain in relation to sulfate sorption. Soil Science, $\mathbf{1 6 8}$, 718-729.

Blakemore, L.C., Searle, P.L. \& Daly, B.K., 1987. Methods for chemical analysis of soils. NZ Soil Bureau Scientific Report 80. Department of Scientific and Industrial Research, Lower Hutt, New Zealand.

Blume, H. \& Schwertmann, U. 1969. Genetic evaluation of profile distribution of aluminum, iron, and manganese oxides. Soil Science Society of America Proceedings, 33, 438-444.

Borggaard, O. K. 1983. The influence of iron oxides on phosphate adsorption by soil. Journal of Soil Science, 34, 333-341.

Caner, L., Bourgeon, G., Toutain, F. \& Herbillon, A. J. 2000. Characteristics of non-allophanic Andisols derived from low-activity clay regoliths in the Nilgiri Hills (Southern India). European Journal of Soil Science, 51, 553-563.

Caner, L., Petit, S., Joussein, E., Fritsch, E. \& Herbillon, A. J. 2011. Accumulation of organo-metallic complexes in laterites and the formation of Aluandic Andosols in the Nilgiri Hills (southern India): similarities and differences with Umbric Podzols. European Journal of Soil Science, 62, 754-764.

Delfosse, T., Delmelle, P. \& Delvaux, B. 2006. Sulphate sorption at high equilibrium concentration in Andosols. Geoderma, 136, 716-722.

Delmelle, P., Delfosse, T., \& Delvaux, B. 2003. Sulfate, chloride and fluoride retention in Andosols exposed to volcanic acid emissions. Environmental Pollution, 126, 445-457.

Delvaux, B., Strebl, F., Maes, E., Herbillon, A. J., Brahy, V. \& Gerzabek, M. 2004. An Andosol-Cambisol toposequence on granite in the Austrian Bohemian Massif. Catena, 56, 31-43.

Hasan, S.M., Fox, R.L. \& Boyd, C.C. 1970. Solubility and availability of sorbed sulfate in Hawaiian soils. Soil Science Society of America Proceedings, 34, 897-901.

Ishiguro, M., Hattori, Y., Makino, T. \& Akae, T. 2004. Adsorption Isotherm of Sulfate on an Allophanic Andisol. Transactions of JSIDRE, 230, 187-192. (In Japanese with English summary)

IUSS Working Group WRB. 2006. World Reference Base for Soil Resources 2006, World Soil Resources Reports No.103, FAO, Rome.

Johnson, D.W., \& Todd, D.E. 1983. Relationships among iron, aluminum, carbon, and sulfate in a variety of forest soils. Soil Science Society of America Journal, 47, 792-800.

Kamprath, E.J., W.L.Nelson, \& Fitts, W.L. 1956. The effect of $\mathrm{pH}$, sulfate and phosphate concentrations on the adsorption of sulfate by soils. Soil Science Society of America Proceedings, 20, 463-166.

Kubotera, H., Masuda, Y. \& Shoji, A. 2009. A profile of Kuroboku soil with non-allophanic and allophanic horizons in Kuju Plateau, Kyushu, Japan. Pedologist, 53, 11-20. (In Japanese with English summary)

Martinez, C.E., Kleinschmidt, A.W. \& Tabatabai, M.A. 1998. Sulfate adsorption by variable charge soils: Effect of low-molecular-weight organic acids. Biology \& Fertility of Soils, 26, 157-163.

Nagatsuka, S. 1972. Studies on genesis and classification of soils in warm-temperate region of Southwest Japan: Part 3. Some features in distribution and mode of existence of free iron. Soil Science \& Plant Nutrition, 18, 147-154.

Nodvin, S.C., Driscoll, C.T., \& Likens, G.E. 1986. The effect of $\mathrm{pH}$ on sulfate adsorption by a forest soil. Soil Science, 142, 69-75.

Obara, H., Ohkura, T. Takata, Y. Kohyama, K. Maejima, Y. \& Hamazaki, T. 2011. Comprehensive soil classification system of japan first approximation. Bulletin of National Institute for Agro-Environmental Science, 29, 1-73. (In Japanese with English summary)

Parfitt, R.L., \& Childs, C.W. 1988. Estimation of forms of Fe and $\mathrm{Al}-\mathrm{a}$ review, and analysis of contrasting soils by dissolution and Mossbauer methods. Australian Journal of Soil Research, 26, 121-144.

Pigna, M., \& Violante, A. 2003. Adsorption of Sulfate and Phosphate on Andisols. Communications in Soil Science \& Plant Analysis, 34, 2099-2113. 
Rajan, S. 1978. Sulfate adsorbed on hydrous alumina, ligands displaced, and changes in surface charge. Soil Science Society of America Journal, 42, 39-44.

Saigusa, M., \& Matsuyama, N. 1998. Distribution of allophanic Andosols and non-allophanic Andosols in Japan. Tohoku Journal of Agricultural Research, 48, 7483.

Shoji, S. 1985. Genesis and properties of non-allophanic andisols in Japan. Applied Clay Science, 1, 83-88.

Shoji, S., \& Ono, T. 1978. Physical and chemical properties and clay mineralogy of andosols from Kitakami, Japan. Soil Science, 126, 297-312.

Shoji, S., Nanzyo, M. \& Dahlgren, R.A. 1993. Volcanic Ash Soils. Genesis, Properties and Utilization, Developments in Soil Science, Volume 21. Elsevier, Amsterdam, Amsterdam, the Netherlands.

Singh, B.R. 1980. Distribution of total and extractable s and adsorbed ${ }^{35} \mathrm{SO}_{4}{ }^{2-}$ in some acid forest soil profiles of southern Norway. Acta Agriculturae Scandinavica, 30, 357-363.

Soil Survey Staff. 1990. Keys to Soil Taxonomy, fourth edition. SMSS Technical Monograph No.19. Blacksburg, Virginia, USA.

Soil Survey Staff. 2004. Soil Survey Laboratory Manual Methods. Soil Survey Laboratory and Investigation Report No 42, U.S. Government Printing Office, Washington, DC, USA.
Soil Survey Staff. 2010. Keys to Soil Taxonomy, 11th ed. USDA-Natural Resources Conservation Service, Washington, DC, USA.

Takahashi, J. \& Higashi, T. 2013. Vertical distributions and the amounts of sulfate in different types of forest soils from Hokuriku district, Japan. Pedologist, 57, 12-26. (In Japanese with English summary)

Tanikawa, T., Takahashi, M., Imaya, A., Inagaki, Y. \& Ishizuka, K. 2003. Vertical distributions and accumulations of sulfate in Andisols and Inceptisolsadsorbed and soluble sulfate fractions. Japanese Journal of Soil Science and Plant Nutrition, 74, 149-155. (In Japanese with English summary)

Vacca, A., Adamo, P., Pigna, M. \& Violante, P. 2003. Genesis of tephra-derived soils from the Roccamonfina volcano, south central Italy. Soil Science Society of America Journal, 67, 198-207.

Vacca, S., Capra, G.F., Coppola, E., Rubino, M., Madrau, S., Colella, A. et al. 2009. From andic non-allophanic to non-andic allophanic Inceptisols on alkaline basalt in Mediterranean climate. Geoderma, 151, 157-167.

Van Ranst, E., Utami, S.R., Verdoodt, A., \& Qafoku, N.P. 2008. Mineralogy of a perudic Andosol in central Java, Indonesia. Geoderma, 144, 379-386. 